\title{
Comparison of Evaluation Tests for Compressive Strength of Structural Concrete
}

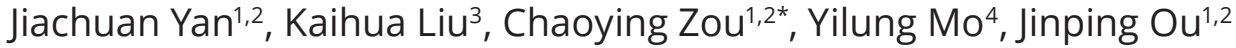 \\ ${ }^{1}$ Key Lab of Structures Dynamic Behaviour and Control of the Ministry of Education, Harbin Institute of Technology, Harbin, \\ 150090, China \\ ${ }^{2}$ Key Lab of Smart Prevention and Mitigation of Civil Engineering Disasters of the Ministry of Industry and Information \\ Technology, Harbin Institute of Technology, Harbin, 150090, China \\ ${ }^{3}$ School of Civil and Transportation Engineering, Guangdong University of Technology, Guangzhou, 510006, China \\ ${ }^{4}$ Department of Civil and Environmental Engineering, University of Houston, 4800 Calhoun, Houston, 77204, USA \\ ${ }^{*}$ Corresponding author, e-mail:
}

Received: 17 May 2019, Accepted: 12 January 2020, Published online: 12 March 2020

\begin{abstract}
The concrete strength of existing structures is an important index in the aspects of safety insurance, evaluation, and strengthening of existing structures. However, different testing methods are used to evaluate the concrete strength, which provide information with different reliability, and the results are thus difficult to be unified. This paper investigated the evaluation tests for compressive strength of structural concrete. The compressive strength of field-cured, standard-cured and core samples, and the rebound method calculated strength of structural concrete were obtained. The results showed that the compressive strength of field-cured and core specimens, and the rebound method calculated strength cannot reach that of standard-cured specimens at the equivalent age of 28 days. The compressive strength of standard-cured and field-cured specimens can be used to represent that of cores for evaluating the quality of structural concrete. All four strength indexes increased in a logarithmic trend with the increasing equivalent age.
\end{abstract}

Keywords

compressive strength, standard-cured, field-cured, rebound method, core drilling method

\section{Introduction}

The concrete strength of existing structures is an important index of safety insurance, evaluation, and strengthening for existing structures [1-2]. The early load-carrying capacity of concrete structures mainly depends on the compressive strength of concrete. The construction processes of formwork removal, transportation and hoisting of concrete structures would have certain requirements for the compressive strength of concrete. It is necessary to form a scientific and reliable evaluation system to test the compressive strength of concrete with different curing ages [3-8].

During the construction process of concrete structures, the cube specimens under the standard and field curing conditions are generally used to evaluate the compressive strength of structural concrete. Although the strength of cube specimens under the standard and field curing conditions has a certain relationship with that of structural concrete, the casting processes, curing conditions, and stress states of structural concrete are somewhat different; hence the two cube specimens strength are not completely the same with the compressive strength of structural concrete. The test results obtained from the control specimens may not be sufficient or reliable to represent the genuine compressive strength of structural concrete.

In situ non-destructive testing and laboratory testing of drilling core samples are often used in the evaluation of existing concrete structures. As a low-cost and convenient non-destructive method, the rebound method is usually adopted to test and evaluate the compressive strength of structural concrete. In practice, a correlation formula between the rebound value and calculated strength is required for this method. In many cases, the reliability of this method in estimating the concrete strength depends on the accuracy of correlation formula. The flatness and humidity of the surface of structural concrete would also cause deviations in the test results [9-10]. Drilling core samples are widely used in determining the compressive 
strength of structural concrete. As the most reliable estimation of the compressive strength of structural concrete, the strength of cores can be used as a reference for the test results of other non-destructive testing methods. However, the number of cores extracted from the structure might be limited. Drilling concrete core is time-consuming and may also damage the structure [11-15].

The compressive strength of the standard-cured and fieldcured specimens are adopted as the fundamental reference to evaluate the compressive strength of structural concrete according to the ACI 318 Code [16]. When the compressive strength of field-cured specimens cannot meet the requirements, the drilled cores shall be extracted for testing. The CEB-FIP Model Code [17] proposes equations to calculate the compressive strength of concrete at different ages, taking the effects of cement type, temperature and curing condition into consideration. Different testing methods may be used in different construction sites to evaluate the concrete strength considering their different applicability. However, testing methods varies in the reliability of the test results. It is necessary to study the relationship between the compressive strength of the field-cured, standard-cured and core specimens, and the strength calculated by rebound method.

In order to guarantee the construction engineering quality, it is imperative to carry out the study on the evaluation tests of compressive strength for structural concrete. This paper investigated the compressive strength of structural concrete with two mineral admixtures (fly ash and slag powder) and four strength grades (C30, C40, C50 and C60) by the destructive tests of 488 specimens according to current Chinese codes [18-22]. The relationship of different compressive strength indexes was established and their development trends were also discussed.

\section{Experimental program}

\subsection{Test materials}

Ordinary Portland cement P.O 42.5 with a standard compressive strength of $51.7 \mathrm{MPa}$ at 28 days was used. Natural river sand and gravel were used as fine aggregate and coarse aggregate, respectively. Four strength grades of concrete were designed, i.e. C30, C40, C50 and C60. The maximum aggregate size of the gravel was $31.5 \mathrm{~mm}$ for the $\mathrm{C} 30, \mathrm{C} 40$ and $\mathrm{C} 50$ concrete, and $20 \mathrm{~mm}$ for the C60 concrete. The mineral admixtures were fly ash of grade II class $\mathrm{F}$ and the slag powder of grade S95. The pumping agent SK202 (water-reducing rate is $14 \%$ ) was used for C30, C40 and $\mathrm{C} 50$ concrete, and the water reducing agent SKPCA (water-reducing rate is $29 \%$ ) was used for C60 concrete.
Table 1 Mix proportions of concrete $\left(1 \mathrm{~m}^{3}\right)$

\begin{tabular}{lccccccc}
\hline ID & $\begin{array}{c}\text { Cement } \\
(\mathrm{kg})\end{array}$ & $\begin{array}{c}\text { Fly ash } \\
(\mathrm{kg})\end{array}$ & $\begin{array}{c}\text { Slag } \\
\text { Powder } \\
(\mathrm{kg})\end{array}$ & $\begin{array}{c}\text { Sand } \\
(\mathrm{kg})\end{array}$ & $\begin{array}{c}\text { Gravel } \\
(\mathrm{kg})\end{array}$ & $\begin{array}{c}\text { Agent } \\
(\mathrm{kg})\end{array}$ & w/c \\
\hline C30F & 300 & 80 & - & 795 & 1000 & 9.5 & 0.46 \\
C30FS & 230 & 80 & 70 & 800 & 1000 & 9.5 & 0.45 \\
C40F & 370 & 80 & - & 740 & 1004 & 15.5 & 0.38 \\
C40FS & 300 & 80 & 70 & 740 & 1009 & 15.5 & 0.37 \\
C50F & 440 & 50 & - & 700 & 1020 & 20 & 0.35 \\
C50FS & 370 & 50 & 70 & 705 & 1020 & 20 & 0.34 \\
C60F & 490 & 50 & - & 670 & 1039 & 10.5 & 0.30 \\
C60FS & 410 & 50 & 70 & 670 & 1044 & 10.5 & 0.29 \\
\hline
\end{tabular}

\subsection{Mix proportion}

For each strength grade, two different mix proportions were used, which were group $F$ of single admixture (fly ash) and group $F S$ of compound admixtures (fly ash and slag powder). Table 1 shows mix proportions of concrete.

\subsection{Specimen design}

Concrete walls (to be drilled for obtaining core specimens) and cube specimens were prepared in this study (Fig. 1). The size of concrete walls was $2000 \times 1000 \times 500 \mathrm{~mm}$. Concrete walls were formed by the mechanical vibration, in accordance with the "Code for acceptance of constructional quality of concrete structures" (GB 50204-2015) strictly [18]. Cores with diameters of $50 \mathrm{~mm}, 75 \mathrm{~mm}$ and $100 \mathrm{~mm}$ were extracted from walls at different specified ages in accordance with the CECS03-2007 [19]. The size of cube specimens for C30, C40 and C50 concrete was $100 \times 100 \times 100 \mathrm{~mm}$, and $150 \times 150 \times 150 \mathrm{~mm}$ for C60 concrete. Cube specimens were formed by the timing vibration table and vibrated at the same time

The formwork of cube specimens was removed after cube specimens were cured for $24 \mathrm{~h}$ in the field condition. Standard-cured specimens were placed in a standard curing room where the temperature was $20 \pm 2{ }^{\circ} \mathrm{C}$ and the relative humidity was over $95 \%$. The field-cured cubes were placed beside the concrete walls and cured in the field condition. The formwork of walls was removed after 3 days in the field condition. The field-cured walls and cubes were cured in wet condition for 14 days. The water was applied 6-8 times during the daytime to ensure the surface of concrete was wet, and the fieldcured specimens and walls were covered with plastic cloth after watering. 


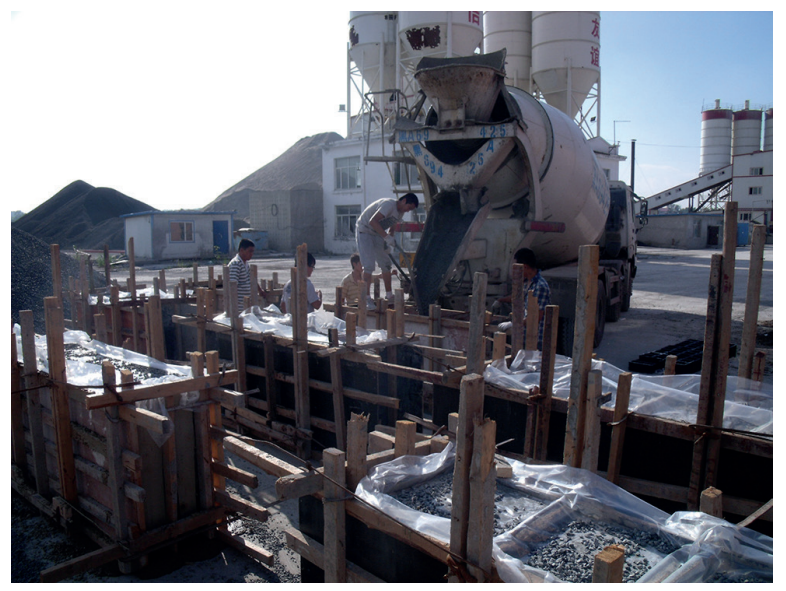

(a) Casting concrete

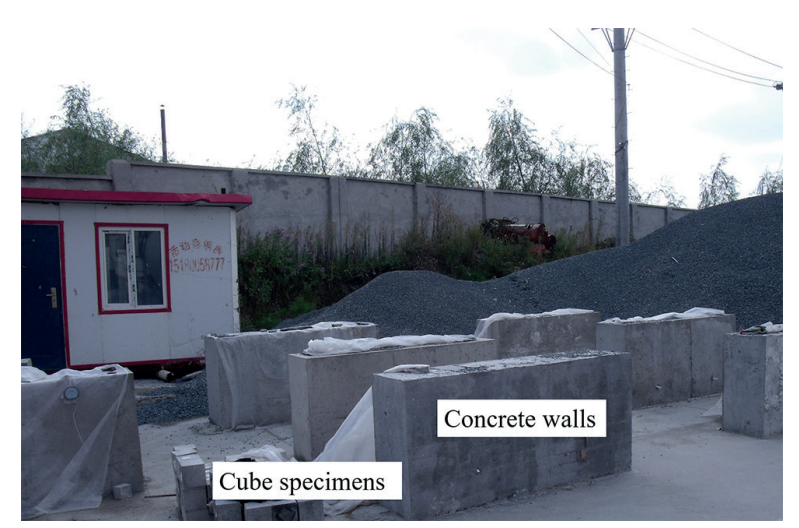

(b) Concrete walls and cubes

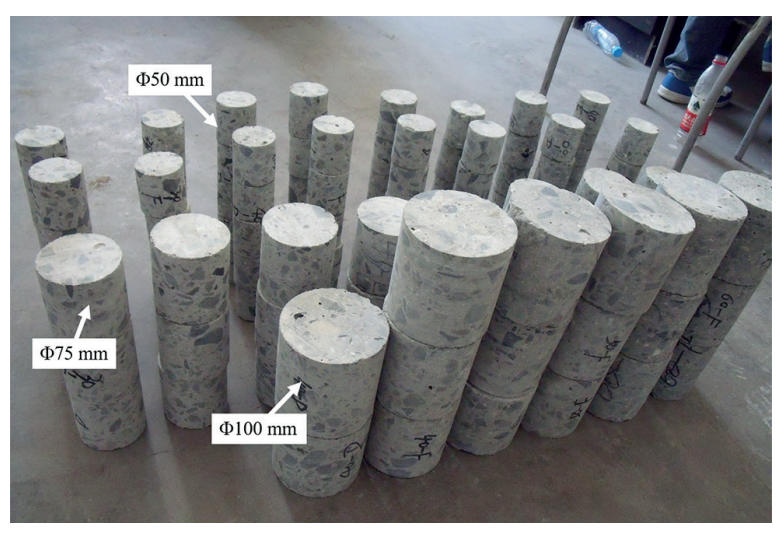

(c) Core samples

Fig. 1 Preparation for specimens

\subsection{Testing program}

The temperature of field condition was recorded hourly. The everyday average temperature of field condition for 258 days is shown in Fig. 2. In order to take the curing temperature into consideration, the equivalent age $t_{\mathrm{T}}$ was calculated for the field-cured specimens and walls. According to "Code for acceptance of constructional quality of concrete structures" (GB 50204-2015) [18], the formula for can be calculated as follows:

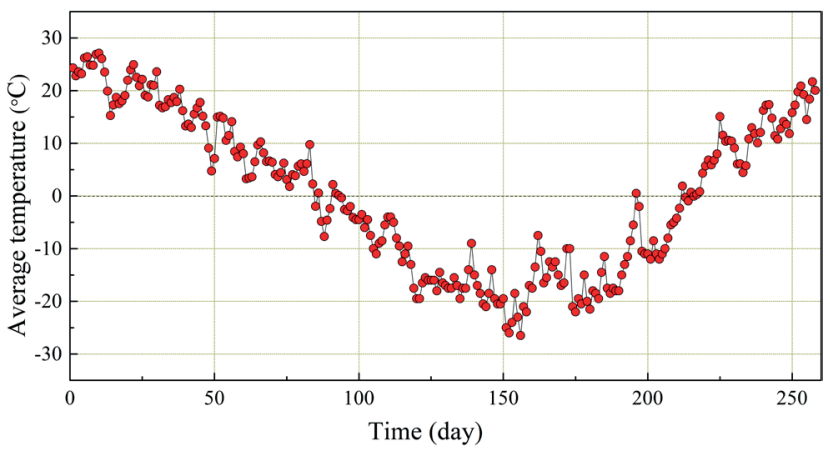

Fig. 2 Average temperature of field condition

$t_{\mathrm{T}}=\sum_{i=1}^{n}\left(\alpha_{\mathrm{T}} \Delta t_{i}\right)$

$\alpha_{\mathrm{T}}=\exp \left[4.26-375 /\left(68+T_{i}\right)\right]$,

where $\alpha_{\mathrm{T}}$ the correction factor of the age corresponding to the $i$ th temperature, $\Delta t$ the days corresponding to the $i$ th temperature (d), $T_{i}$ the $i$ th temperature, determined by the daily average temperature of field condition.

In order to investigate the development trend of concrete strength at different ages, the ages of standard-cured specimens were specified as $7 \mathrm{~d}, 14 \mathrm{~d}, 28 \mathrm{~d}, 60 \mathrm{~d}, 90 \mathrm{~d}$ and $180 \mathrm{~d}$; the equivalent ages of the field-cured specimens were specified as $7 \mathrm{~d}, 14 \mathrm{~d}, 28 \mathrm{~d}, 60 \mathrm{~d}$ and $90 \mathrm{~d}$; the equivalent ages of walls were specified as $28 \mathrm{~d}, 60 \mathrm{~d}$ and $90 \mathrm{~d}$. Corresponding to each specified age, the tests of compressive strength of cube specimens, rebound strength of concrete walls and compressive strength of core samples were carried out in the same day. Three cube specimens were taken to conduct the compressive test for each situation and ten cores of $\Phi 50 \mathrm{~mm}$ were extracted in order to avoid the effect of scattered results for small samples, while three cores of $\Phi 75 \mathrm{~mm}$ and $\Phi 100 \mathrm{~mm}$ were obtained. The details of specimens are shown in Table 2. The procedure of the rebound test was performed in accordance with the JGJ/T23-2011 [20].

\section{Experimental results \\ 3.1 Test results}

The procedure of the compressive tests for cubes and core specimens was in accordance with the GB/T 500812002 [21]. The results of standard-cured cubes $f_{\text {cu,s }}$ and fieldcured cubes $f_{\text {cu, }}$ are shown in Tables 3 and 4, respectively. The rebound method calculated strength $f_{\mathrm{s}, \mathrm{r}}$ are shown in Table 5 and the results of cores $f_{\mathrm{s}, \mathrm{c}}$ are shown in Table 6 .

As shown in Table 3 to Table 6, the test results of compressive strength for Group F were close to that for group FS. Hence, the results for these two groups were integrated 
Table 2 The details of specimens

\begin{tabular}{|c|c|c|c|}
\hline $\begin{array}{l}\text { Specimen } \\
\text { type }\end{array}$ & Concrete mixture & Size $(\mathrm{mm})$ & $\begin{array}{l}\text { Specified } \\
\text { age (d) }\end{array}$ \\
\hline \multirow{2}{*}{$\begin{array}{l}\text { Standard- } \\
\text { cured cubes }\end{array}$} & $\begin{array}{c}\mathrm{C} 30 \mathrm{~F}, \mathrm{C} 40 \mathrm{~F}, \mathrm{C} 50 \mathrm{~F}, \\
\mathrm{C} 30 \mathrm{FS}, \mathrm{C} 40 \mathrm{FS}, \\
\mathrm{C} 50 \mathrm{FS}\end{array}$ & $100 \times 100 \times 100$ & $\begin{array}{c}7,14,28,60 \\
90,180\end{array}$ \\
\hline & C60F C60FS & $150 \times 150 \times 150$ & $\begin{array}{c}7,14,28,60 \\
90,180\end{array}$ \\
\hline \multirow{2}{*}{$\begin{array}{l}\text { Field-cured } \\
\text { cubes }\end{array}$} & $\begin{array}{c}\mathrm{C} 30 \mathrm{~F}, \mathrm{C} 40 \mathrm{~F}, \mathrm{C} 50 \mathrm{~F}, \\
\mathrm{C} 30 \mathrm{FS}, \mathrm{C} 40 \mathrm{FS}, \\
\text { C50FS }\end{array}$ & $100 \times 100 \times 100$ & $\begin{array}{c}7,14,28 \\
60,90\end{array}$ \\
\hline & C60F, C60FS & $150 \times 150 \times 150$ & $\begin{array}{c}7,14,28 \\
60,90\end{array}$ \\
\hline \multirow{3}{*}{$\begin{array}{l}\text { Drilled } \\
\text { cores }\end{array}$} & $\mathrm{C} 30 \mathrm{~F}, \mathrm{C} 40 \mathrm{~F}, \mathrm{C} 50 \mathrm{~F}$, & $\mathrm{F} 100 \times 100$ & $28,60,90$ \\
\hline & $\begin{array}{c}\mathrm{C} 60 \mathrm{~F}, \mathrm{C} 30 \mathrm{FS} \\
\mathrm{C} 40 \mathrm{FS}\end{array}$ & $\mathrm{F} 75 \times 75$ & $28,60,90$ \\
\hline & C50FS, C60FS & $\mathrm{F} 50 \times 50$ & 28 \\
\hline
\end{tabular}

in the analysis of test results. The comparison among four compressive strength indexes with different ages was shown below.

\subsubsection{Comparison between $\boldsymbol{f}_{\mathrm{cu}, \mathrm{s}}$ and $\boldsymbol{f}_{\mathrm{cu}, \mathrm{f}}$}

Although a conclusion may review the main points of the paper, do not replicate the abstract as the conclusion. A conclusion might elaborate on the importance of the work or suggest applications and extensions.

In order to investigate the effect of curing conditions on the compressive strength, the results of standard-cured cube $f_{\mathrm{cu}, \mathrm{s}}$ and field-cured cubes $f_{\mathrm{cu}, \mathrm{f}}$ with different ages were compared as shown in Fig. 3. For each equivalent age, the average value of the ratio between $f_{\mathrm{cu}, \mathrm{f}}$ and $f_{\mathrm{cu}, \mathrm{s}}$ was denoted as .

It can be seen from Fig. 3 that when the equivalent ages were $7 \mathrm{~d}$ and $14 \mathrm{~d}, R_{\mathrm{f} / \mathrm{s}, 7 \mathrm{~d}}=R_{\mathrm{f} / \mathrm{s}, 14 \mathrm{~d}}=0.826$. This may be due to the similar curing condition for field-cured and standard-cured cubes, which can ensure the required moisture for the hydration process of cement, the compressive strength of field-cured and standard-cured cube specimens increased in the same pace. When $t_{\mathrm{T}}$ varied from $14 \mathrm{~d}$ to $28 \mathrm{~d}$, the humidity of the field-cured specimens dropped, which made the hydration react slowly and reduced the

Table 3 Compressive strengths of standard-cured cube specimens (MPa)

\begin{tabular}{|c|c|c|c|c|c|c|c|c|}
\hline \multirow{2}{*}{ Age (d) } & \multicolumn{8}{|c|}{ Concrete mixture } \\
\hline & $\mathrm{C} 30 \mathrm{~F}$ & $\mathrm{C} 40 \mathrm{~F}$ & $\mathrm{C} 50 \mathrm{~F}$ & $\mathrm{C} 60 \mathrm{~F}$ & C30FS & C40FS & C50FS & C60FS \\
\hline 7 & 25.4 & 40.5 & 49.7 & 39.6 & 24.5 & 41.5 & 49.0 & 50.0 \\
\hline 14 & 27.2 & 45.7 & 52.8 & 47.9 & 26.0 & 47.9 & 51.0 & 57.8 \\
\hline 28 & 36.4 & 53.9 & 54.3 & 55.1 & 38.1 & 59.9 & 61.7 & 60.2 \\
\hline 60 & 41.8 & 56.1 & 62.3 & 60.7 & 43.6 & 61.4 & 66.0 & 63.5 \\
\hline 90 & 44.9 & 62.5 & 64.4 & 61.9 & 47.1 & 58.3 & 64.3 & 58.7 \\
\hline 180 & 48.3 & 58.9 & 70.4 & 62.5 & 47.4 & 64.5 & 55.9 & 63.7 \\
\hline
\end{tabular}

Table 4 Compressive strengths of field-cured cubes (MPa)

\begin{tabular}{|c|c|c|c|c|c|c|c|c|}
\hline \multirow{2}{*}{$\begin{array}{l}\text { Equivalent } \\
\text { age (d) }\end{array}$} & \multicolumn{8}{|c|}{ Concrete mixture } \\
\hline & $\mathrm{C} 30 \mathrm{~F}$ & $\mathrm{C} 40 \mathrm{~F}$ & $\mathrm{C} 50 \mathrm{~F}$ & C60F & C30FS & C40FS & C50FS & C60FS \\
\hline 7 & 20.8 & 31.8 & 36.8 & 35.2 & 20.7 & 34.9 & 39.1 & 44.1 \\
\hline 14 & 23.8 & 34.1 & 41.1 & 39.4 & 23.8 & 37.7 & 44.8 & 46.7 \\
\hline 28 & 31.2 & 43.3 & 44.3 & 42.7 & 31.0 & 45.2 & 49.2 & 50.4 \\
\hline 60 & 41.3 & 50.9 & 61.6 & 57.4 & 38.7 & 53.7 & 54.3 & 59.9 \\
\hline 90 & 44.8 & 60.4 & 68.2 & 61.1 & 47.3 & 61.6 & 66.9 & 63.7 \\
\hline
\end{tabular}

Table 5 Rebound method calculated strength (MPa)

\begin{tabular}{|c|c|c|c|c|c|c|c|c|}
\hline \multirow{2}{*}{$\begin{array}{l}\text { Equivalent } \\
\text { age (d) }\end{array}$} & \multicolumn{8}{|c|}{ Concrete mixture } \\
\hline & $\mathrm{C} 30 \mathrm{~F}$ & $\mathrm{C} 40 \mathrm{~F}$ & $\mathrm{C} 50 \mathrm{~F}$ & $\mathrm{C} 60 \mathrm{~F}$ & C30FS & C40FS & C50FS & C60FS \\
\hline 28 & 26.4 & 35.2 & 37.6 & 38.2 & 28.0 & 38.6 & 47.2 & 43.6 \\
\hline 60 & 34.5 & 47.9 & 50.3 & 48.8 & 35.1 & 48.0 & 57.2 & 53.4 \\
\hline 90 & 33.8 & 52.0 & 52.4 & 50.9 & 35.4 & 47.7 & 59.8 & 55.8 \\
\hline
\end{tabular}


Table 6 Compressive strengths of cores $(\mathrm{MPa})$

\begin{tabular}{|c|c|c|c|c|c|c|c|c|c|}
\hline \multirow{2}{*}{$\begin{array}{l}\text { Size } \\
(\mathrm{mm})\end{array}$} & \multirow{2}{*}{$\begin{array}{l}\text { Equivalent } \\
\text { age (d) }\end{array}$} & \multicolumn{8}{|c|}{ Concrete mixture } \\
\hline & & $\mathrm{C} 30 \mathrm{~F}$ & $\mathrm{C} 40 \mathrm{~F}$ & $\mathrm{C} 50 \mathrm{~F}$ & $\mathrm{C} 60 \mathrm{~F}$ & C30FS & C40FS & C50FS & C60FS \\
\hline \multirow[t]{2}{*}{$\Phi 50$} & 28 & 26.8 & 42.6 & 41.2 & 42.7 & 31.0 & 44.4 & 49.8 & 53.9 \\
\hline & 28 & 27.0 & 42.3 & 40.6 & 42.3 & 30.5 & 44.7 & 52.5 & 54.8 \\
\hline \multirow[t]{3}{*}{$\Phi 75$} & 60 & 39.4 & 55.3 & 55.4 & 61.4 & 43.1 & 57.5 & 68.4 & 63.9 \\
\hline & 90 & 39.3 & 53.4 & 56.1 & 63.4 & 42.1 & 57.8 & 65.8 & 62.7 \\
\hline & 28 & 28.7 & 41.9 & 44.4 & 40.1 & 29.5 & 44.9 & 48.5 & 51.1 \\
\hline \multirow[t]{2}{*}{$\Phi 100$} & 60 & 41.5 & 54.8 & 58.6 & 58.1 & 38.9 & 57.4 & 63.2 & 59.6 \\
\hline & 90 & 45.0 & 57.7 & 59.7 & 63.4 & 45.9 & 58.2 & 70.5 & 60.1 \\
\hline
\end{tabular}

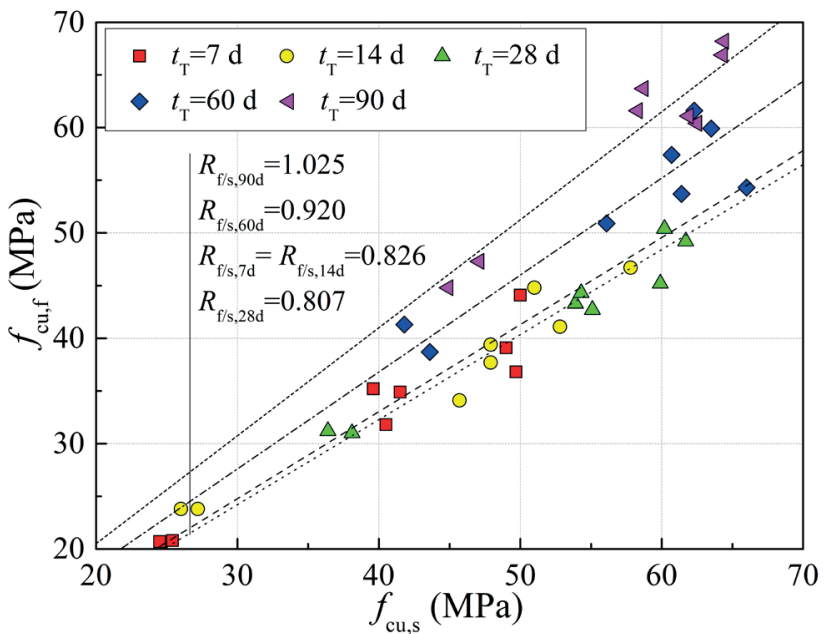

Fig. 3 Comparison between $f_{\text {cu, }}$ and $f_{\text {cu, s }}$ in different ages

development of concrete strength during this period. When $t_{\mathrm{T}}$ reached $28 \mathrm{~d}$, the hydration of specimens under the standard curing condition was basically completed, whereas the compressive strength of field-cured specimens was still developing. The ratio of $f_{\mathrm{cu}, \mathrm{f}} / f_{\mathrm{cu}, \mathrm{s}}$ had an increasing trend with the increasing age. When $t_{\mathrm{T}}$ was more than $60 \mathrm{~d}$, the compressive strength of field-cured specimens tended to be equal to that of standard-cured specimens.

\subsubsection{Comparison between $f_{\mathrm{s}, \mathrm{c}}$ and $\boldsymbol{f}_{\mathrm{cu}, \mathrm{s}}$}

The comparison between the compressive strengths of cores $f_{\mathrm{s}, \mathrm{c}}$ and standard-cured cubes $f_{\mathrm{cu}, \mathrm{s}}$ was shown in Fig. 4. For each equivalent age, the average value of the ratio between $f_{\mathrm{s}, \mathrm{c}}$ and $f_{\mathrm{cu}, \mathrm{s}}$ was denoted as $R_{\mathrm{c} / \mathrm{s}}$.

It can be seen from Fig. 4 that when $t_{\mathrm{T}}$ was $28 \mathrm{~d}$, $R_{\mathrm{c} / \mathrm{s}, 28 \mathrm{~d}}=0.784$, which indicated that the compressive strength of cores cannot reach the compressive strength of standard-cured cubes in the equivalent age of $28 \mathrm{~d}$. Therefore, when evaluating the quality of structural concrete in the equivalent age of $28 \mathrm{~d}$, it was generally unrealistic to require the compressive strength of structural concrete to reach that of standard-cured cubes. When $t_{\mathrm{T}}$

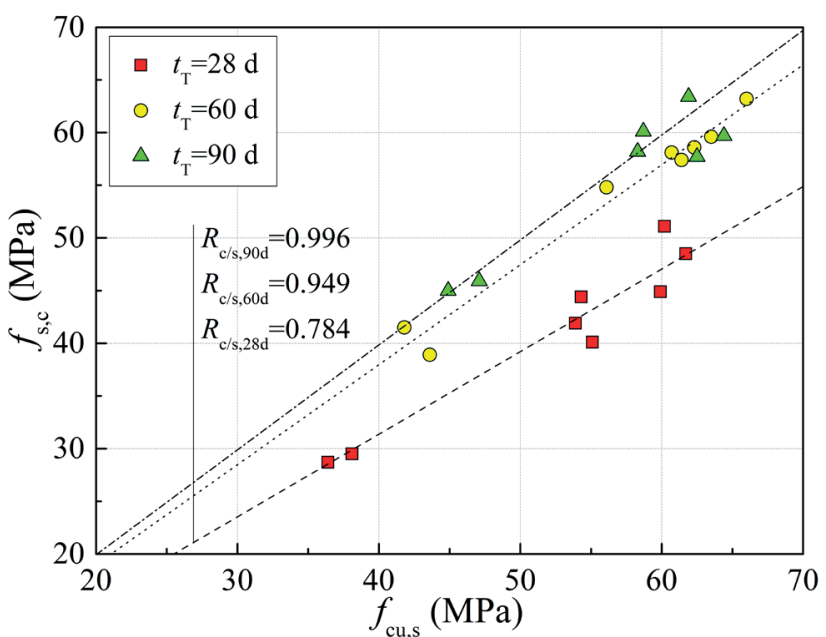

Fig. 4 Comparison between $f_{\mathrm{s}, \mathrm{c}}$ and $f_{\mathrm{cu}, \mathrm{s}}$ in different ages

was $60 \mathrm{~d}, R_{\mathrm{c} / \mathrm{s}, 28 \mathrm{~d}}=0.949$, i.e. the compressive strength of cores was similar to that of standard-cured cube specimens. After that, the ratio of $f_{\mathrm{s}, \mathrm{c}} / f_{\mathrm{cu}, \mathrm{s}}$ tended to be stable with the increasing equivalent age. When $t_{\mathrm{T}}$ was $90 \mathrm{~d}$, the ratio of $f_{\mathrm{s}, \mathrm{c}} / f_{\mathrm{cu}, \mathrm{s}}$ was 0.996 . It can be concluded that when $t_{\mathrm{T}}$ was more than $60 \mathrm{~d}$, the effect of curing conditions on the concrete strength can be neglected and the compressive strength of standard-cured specimens can be adopted to represent that of cores for evaluating the compressive strength of structural concrete.

\subsubsection{Comparison between $f_{\mathrm{cu}, \mathrm{f}}$ and $\boldsymbol{f}_{\mathrm{s}, \mathrm{c}}$}

The comparison between the compressive strength of field-cured cubes $f_{\text {cu,f }}$ and core samples $f_{\mathrm{s}, \mathrm{c}}$ is shown in Fig. 5. For each equivalent age, the average value of the ratio between $f_{\text {cu, }}$ and $f_{\mathrm{s}, \mathrm{c}}$ was denoted as $R_{\mathrm{f} / \mathrm{c}}$.

It can be seen from Fig. 5 that during the whole curing period, the ratio of $f_{\mathrm{cu}, \mathrm{f}} / f_{\mathrm{s}, \mathrm{c}}$ was stable around 1.0 (1.031 for $R_{\mathrm{c} / \mathrm{f}, 28 \mathrm{~d}}$ and $R_{\mathrm{c} / \mathrm{f}, 90 \mathrm{~d}}, 0.970$ for $\left.R_{\mathrm{c} / \mathrm{f}, 60 \mathrm{~d}}\right)$, which indicated that the compressive strength of field-cured cubes was close to that of the cores and their test results can represent that of the cores for evaluate the quality of structural concrete. 


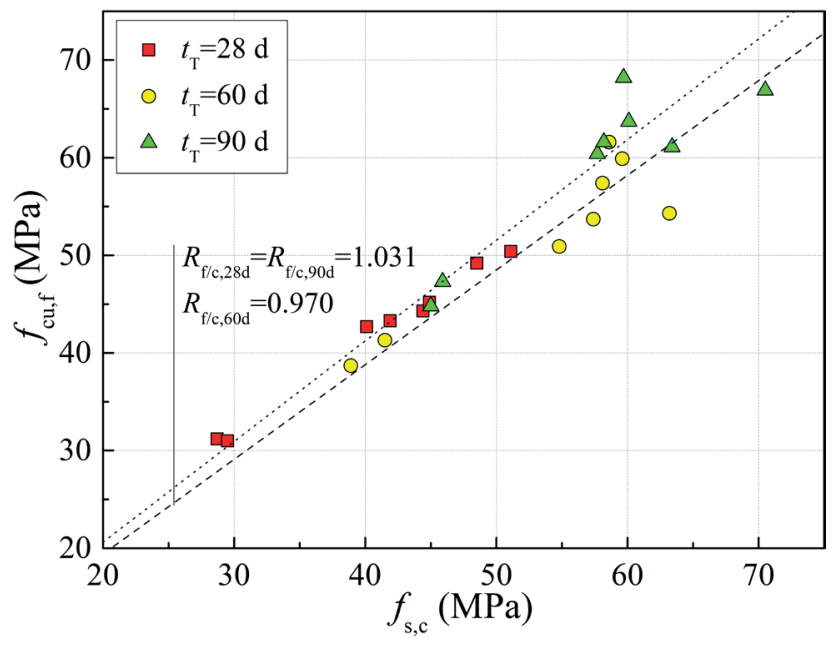

Fig. 5 Comparison between $f_{\mathrm{cu}, \mathrm{f}}$ and $f_{\mathrm{s}, \mathrm{c}}$ with different ages

\subsubsection{Comparison between $\boldsymbol{f}_{\mathrm{s}, \mathrm{r}}$ and $\boldsymbol{f}_{\mathrm{s}, \mathrm{c}}$}

The comparison between the rebound method calculated strength $f_{\mathrm{s}, \mathrm{r}}$ and the compressive strength of cores $f_{\mathrm{s}, \mathrm{c}}$ is shown in Fig. 6. For each equivalent age, the average value of the ratio between $f_{\mathrm{s}, \mathrm{r}}$ and $f_{\mathrm{s}, \mathrm{c}}$ was denoted as $R_{\mathrm{r} / \mathrm{c}}$.

During the whole curing period, the ratios of $f_{\mathrm{s}, \mathrm{r}} / f_{\mathrm{s}, \mathrm{c}}$ were less than 1.0. This could be explained by the fact that the rebound method calculated strength was obtained by the hardness of the wall surface, which was a conversional strength. In contrast, the compressive strength of the cores was not affected by the surface quality of the wall. Therefore, the compressive strength of the cores was larger than the rebound method calculated strength. In addition, the effect of mineral admixtures and agents made the alkalinity of the wall surface decreased and further caused a relatively large measurement value of the carbonation depth, which led to a slightly decrease of $R_{\mathrm{r} / \mathrm{c}}$. During the whole curing period, the ratio of $f_{\mathrm{s}, \mathrm{r}} / f_{\mathrm{s}, \mathrm{c}}$ was

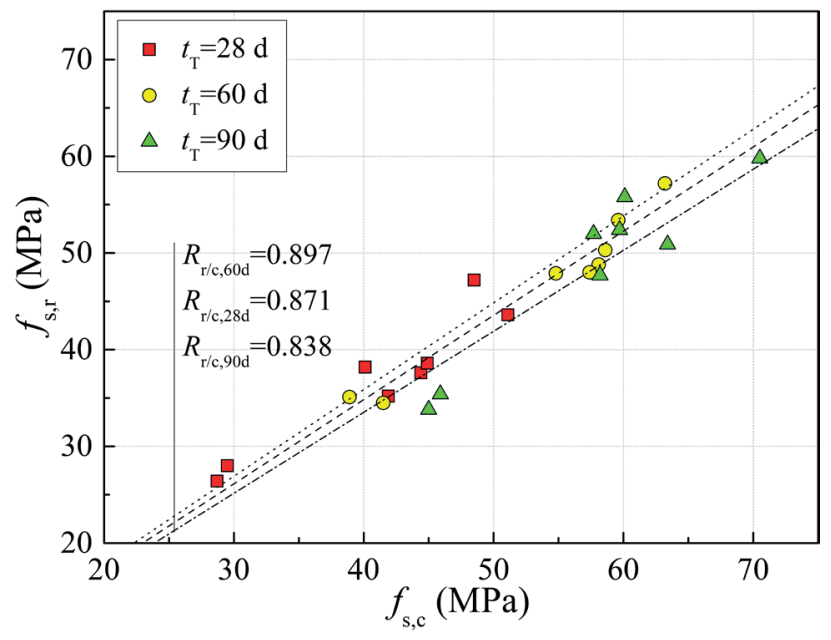

Fig. 6 Comparison between $f_{\mathrm{s}, \mathrm{r}}$ and $f_{\mathrm{s}, \mathrm{c}}$ with different ages stable, which showed that the rebound method calculated strength had a good correlation with the compressive strength of cores.

\subsubsection{Comparison between $\boldsymbol{f}_{\mathrm{s}, \mathrm{c}}^{\Phi 50}, \boldsymbol{f}_{\mathrm{s}, \mathrm{c}}^{\Phi 75}$ and $\boldsymbol{f}_{\mathrm{s}, \mathrm{c}}^{\Phi 100}$}

The comparison between the compression strength of cores with $\Phi 75 \mathrm{~mm}$ and $\Phi 100 \mathrm{~mm}$ is shown in Fig. 7, and similarly, the comparison between the compressive strength of cores with $\Phi 50 \mathrm{~mm}$ and $\Phi 100 \mathrm{~mm}$ is shown in Fig. 8. The height-diameter ratio of all the cores was 1.0. For each equivalent age, the average value of the ratio of $f_{\mathrm{s}, \mathrm{c}}^{\Phi 75} / f_{\mathrm{s}, \mathrm{c}}^{\Phi 100}$ was denoted as $R_{\mathrm{c}}^{75 / 100}$. For equivalent age of $28 \mathrm{~d}$, the average value of the ratio between $f_{\mathrm{s}, \mathrm{c}}^{\Phi 50}$ and $f_{\mathrm{s}, \mathrm{c}}^{\Phi 100}$ was denoted as $R_{\mathrm{c}, 28 \mathrm{~d}}^{50 / 100}$.

The average value of $R_{\mathrm{c}}^{75 / 100}$ was 0.995 and $R_{\mathrm{c}, 28 \mathrm{~d}}^{50 / 100}$ was 1.008. Fig. 7 and Fig. 8 showed that the compressive strength of cores with $\Phi 50 \mathrm{~mm}$ and $\Phi 75 \mathrm{~mm}$ had a good correlation with that of $\Phi 100 \mathrm{~mm}$, and the size effect on

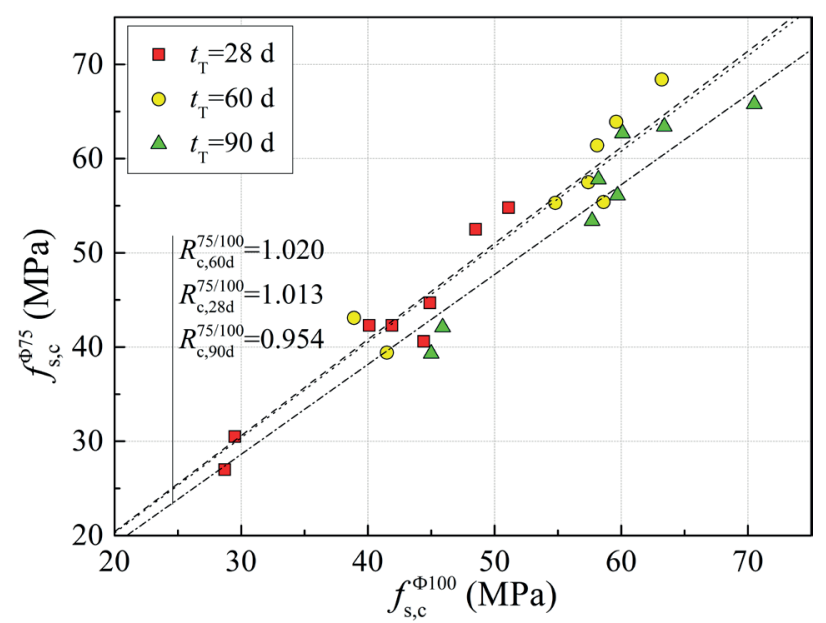

Fig. 7 Comparison between $f_{\mathrm{s}, \mathrm{c}}^{\Phi 50}$ and $f_{\mathrm{s}, \mathrm{c}}^{\Phi 100}$

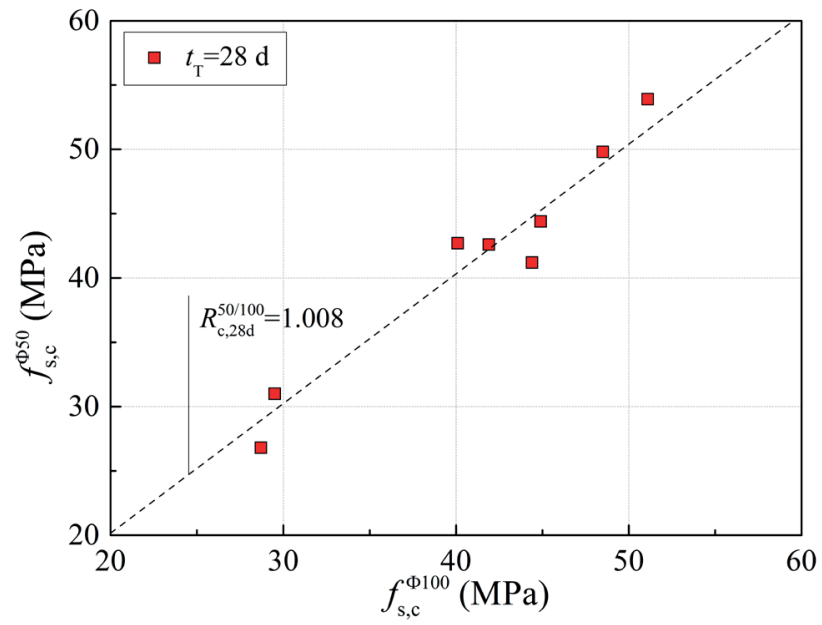

Fig. 8 Comparison between $f_{\mathrm{s}, \mathrm{c}}^{\Phi 50}$ and $f_{\mathrm{s}, \mathrm{c}}^{\Phi 100}$ at $28 \mathrm{~d}$ 
the compressive strength of core samples was not obvious. Theoretically, the compressive strength of small diameter cores may be higher than that of big diameter cores because of the size effect. Besides, the internal defects generally increased with the increasing size of the specimen and the compressive strength decreased correspondingly [22-24]. However, in practice, the process of drilling would increase the cumulative damage of cores. For the specimen with small size, the cumulative damage was more serious. In addition, in the cutting process of cores, the fracture surfaces of aggregates would be produced on the cutting surface. The uneven distribution of the fracture surfaces of aggregates on the cutting surface would decrease the actual compressive strength of cores. For small diameter cores, the proportion between the area of fracture surfaces of aggregates and that of the cross section of the core was larger compared with big diameter cores, which would decrease the compressive strength of concrete core samples. In conclusion, the effect of these two cases above cancelled each other out in this study. The compressive strength of cores did not fluctuate obviously with the change of the core size from $50 \mathrm{~mm}$ to $100 \mathrm{~mm}$.

\subsection{Development trend of concrete strength indexes}

The development trend of four concrete strength indexes with the increasing equivalent ages were discussed in this section. The compressive strength of standard-cured cube specimens of $28 \mathrm{~d} f_{\mathrm{cu}, \mathrm{s}}^{28 \mathrm{~d}}$ was specified as a reference point. The ratios of $f_{c u, s}, f_{c u, f}, f_{s, c}$ and $f_{s, r}$ to $f_{\mathrm{cu}, \mathrm{s}}^{28 \mathrm{~d}}$ for each concrete mixture with different equivalent ages are shown in Fig. 9 to Fig. 12, respectively.

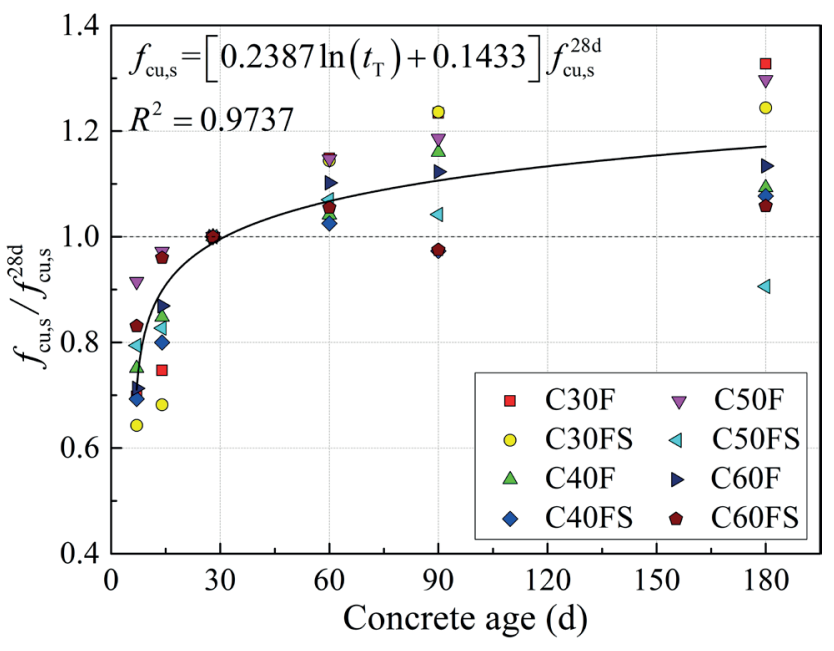

Fig. 9 Ratio of $f_{\mathrm{cu}, \mathrm{s}} / f_{\mathrm{cu}, \mathrm{s}}^{28 \mathrm{~d}}$ with different ages

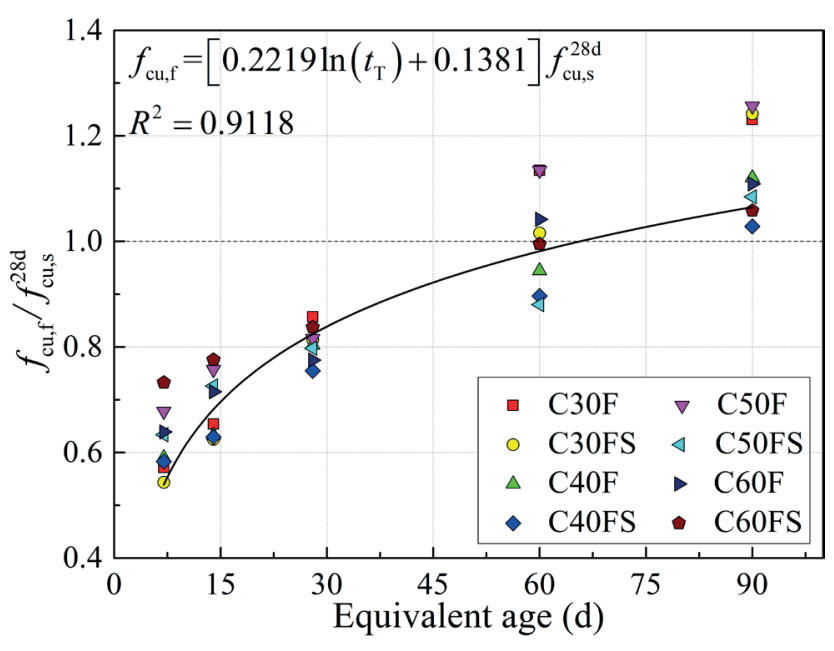

Fig. 10 Ratio of $f_{\mathrm{cu}, \mathrm{f}} / f_{\mathrm{cu}, \mathrm{s}}^{28 \mathrm{~d}}$ with different equivalent ages

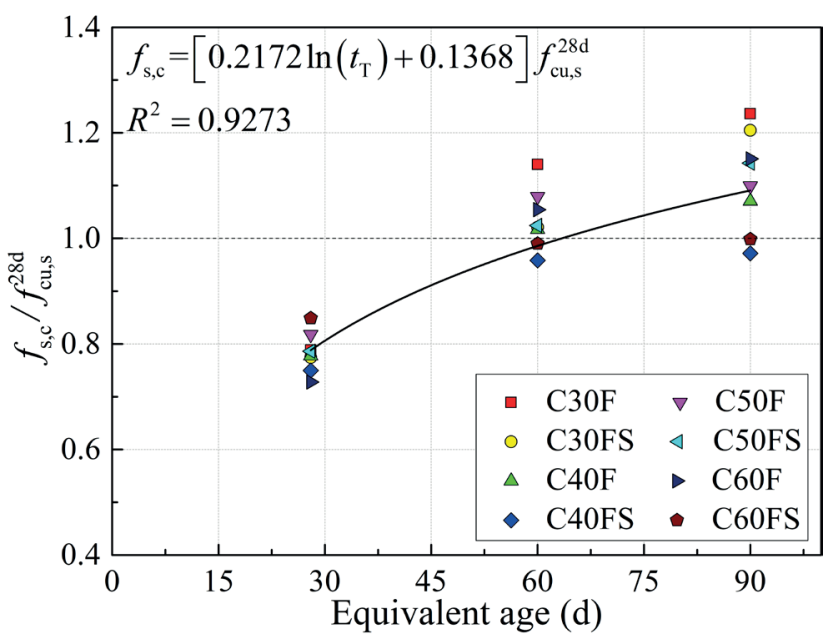

Fig. 11 Ratio of $f_{\mathrm{s}, \mathrm{c}} / f_{\mathrm{cu}, \mathrm{s}}^{28 \mathrm{~d}}$ with different equivalent ages

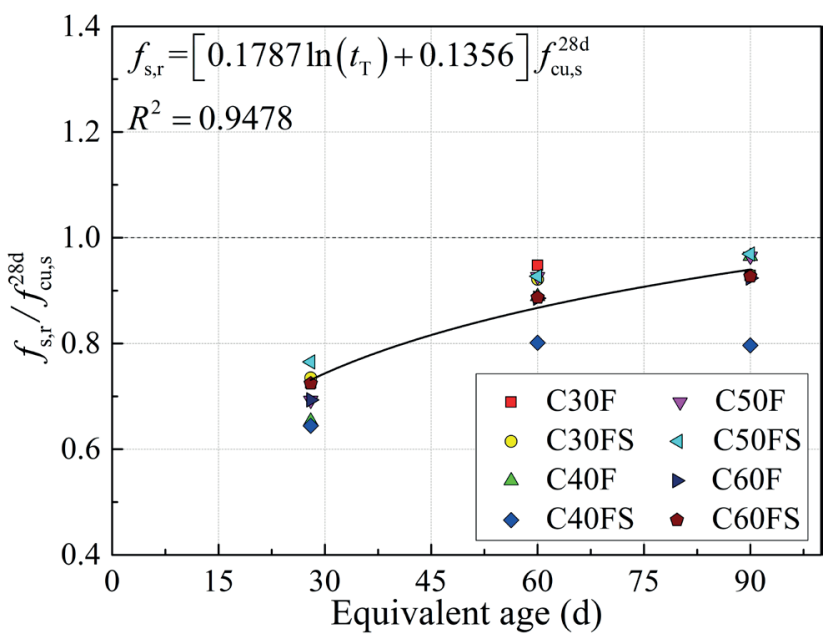

Fig. 12 Ratio of $f_{\mathrm{s}, \mathrm{r}} / f_{\mathrm{cu}, \mathrm{s}}^{28 \mathrm{~d}}$ with different equivalent ages 
According to the ratios $f_{\mathrm{cu}, \mathrm{s}} / f_{\mathrm{cu}, \mathrm{s}}^{28 \mathrm{~d}}, f_{\mathrm{cu}, \mathrm{f}} / f_{\mathrm{cu}, \mathrm{s}}^{28 \mathrm{~d}}, f_{\mathrm{s}, \mathrm{c}} / f_{\mathrm{cu}, \mathrm{s}}^{28 \mathrm{~d}}$, and $f_{\mathrm{s}, \mathrm{r}} / f_{\mathrm{cu}, \mathrm{s}}^{28 \mathrm{~d}}$ for each mixture with different equivalent ages, the statistical fitting formulas of the development trend of four concrete strength indexes with were proposed as follows:

$$
\begin{aligned}
& f_{c u, s}=\left[0.2387 \ln \left(t_{T}\right)+0.1433\right] f_{c u, s}^{28 d}, R^{2}=0.9737 \\
& f_{c u, f}=\left[0.2219 \ln \left(t_{T}\right)+0.1381\right] f_{c u, s}^{28 d}, R^{2}=0.9118 \\
& f_{s, c}=\left[0.2172 \ln \left(t_{T}\right)+0.1368\right] f_{c u, s}^{28 d}, R^{2}=0.9273 \\
& f_{s, r}=\left[0.1787 \ln \left(t_{T}\right)+0.1356\right] f_{c u, s}^{28 d}, \quad R^{2}=0.9478
\end{aligned}
$$

It can be seen from Fig. 9 to Fig. 12, all four ratios of $f_{\mathrm{cu}, \mathrm{s}} / f_{\mathrm{cu}, \mathrm{s}}^{28 \mathrm{~d}}, f_{\mathrm{cu}, \mathrm{f}} / f_{\mathrm{cu}, \mathrm{s}}^{28 \mathrm{~d}}, f_{\mathrm{s}, \mathrm{c}} / f_{\mathrm{cu}, \mathrm{s}}^{28 \mathrm{~d}}$, and $f_{\mathrm{s}, \mathrm{r}} / f_{\mathrm{cu}, \mathrm{s}}^{28 \mathrm{~d}}$ had a good logarithmic correlation with $t_{T}$ When $t_{T}$ was less than $7 \mathrm{~d}$, the compressive strength of standard-cured cube specimens developed rapidly, and the compressive strength of $7 \mathrm{~d}$ can reach more than $70 \%$ of that of $28 \mathrm{~d}$. Afterwards, the growth of the compressive strength slowed down gradually, and when the age was more than $28 \mathrm{~d}$, the compressive strength of standard-cured cube specimens was still growing. Fig. 10 showed that the compressive strength of field-cured cubes of $7 \mathrm{~d}$ can reach more than $60 \%$ of $f_{\mathrm{cus}, \mathrm{s}}^{28 \mathrm{~d}}$. Afterwards, the growth of the compressive strength went slow. When $t_{T}$ was $60 \mathrm{~d}$, the ratio of $f_{\mathrm{cu}, \mathrm{f}} / f_{\mathrm{cu}, \mathrm{s}}^{28 \mathrm{~d}}$ was about 1.0. After that, the ratio of $f_{\mathrm{cu}, \mathrm{f}} / f_{\mathrm{cu}, \mathrm{s}}^{28 \mathrm{~d}}$ was more than 1.0. This indicated that the compressive strength of field-cured cubes can reach $f_{\mathrm{cus}, \mathrm{s}}^{28 \mathrm{~d}}$ with the increasing equivalent age. It can be calculated from Eq. (4) that when $f_{\mathrm{cu}, \mathrm{f}} / f_{\mathrm{cu}, \mathrm{s}}^{28 \mathrm{~d}}$ was $1.0, t_{T}$ was equal to $48 \mathrm{~d}$. This suggested that under the field curing condition of this test, when the compressive strength of cube specimens reached $f_{\mathrm{cus}, \mathrm{s}}^{28 \mathrm{~d}}$, the corresponding equivalent age was $48 \mathrm{~d}$. Therefore, from the view point of the development trend of compressive strength of field-cured cubes, it was not realistic to require the compressive strength of field-cured cubes to reach $f_{\mathrm{cu}, \mathrm{s}}^{28 \mathrm{~d}}$ when $t_{T}$ was $28 \mathrm{~d}$. Fig. 11 revealed that when $t_{T}$ was $28 \mathrm{~d}$, the compressive strength of cores was about $80 \%$ of. When $f_{\mathrm{cu}, \mathrm{s}}^{28 \mathrm{~d}}$ was over $28 \mathrm{~d}$, the compressive strength still rose slowly. The ratio of $f_{\mathrm{s}, \mathrm{c}} / f_{\mathrm{cu}, \mathrm{s}}^{28 \mathrm{~d}}$ was around 1.0 when $t_{T}$ was $60 \mathrm{~d}$. Then, the ratio of $f_{\mathrm{s}, \mathrm{c}} / f_{\mathrm{cus}, \mathrm{s}}^{28 \mathrm{~d}}$ was larger than 1.0. It meant that the compressive strength of cores $f_{\mathrm{s}, \mathrm{c}}$ can reach $f_{\mathrm{cu}, \mathrm{s}}^{28 \mathrm{~d}}$ as $t_{T}$ increased. It can be calculated from Eq. (5) that when $f_{\mathrm{s}, \mathrm{c}} / f_{\mathrm{cu}, \mathrm{s}}^{28 \mathrm{~d}}, t_{T}=53 \mathrm{~d}$. This suggested that when the compressive strength of cores reached $f_{\mathrm{cu}, \mathrm{s}}^{28 \mathrm{~d}}$, the corresponding equivalent age was $53 \mathrm{~d}$ under the field curing condition of this test. Fig. 12 showed that when $t_{T}$ was
$28 \mathrm{~d}$, the rebound method calculated strength was roughly $70 \%$ of $f_{\mathrm{cus}, \mathrm{s}}^{28 \mathrm{~d}}$. When $t_{T}$ was over $28 \mathrm{~d}$, the rebound method calculated strength gradually increased. However, when $t_{T}$ was more than $60 \mathrm{~d}$, the rebound method calculated strength still cannot reach $f_{\mathrm{cu}, \mathrm{s}}^{28 \mathrm{~d}}$. It can be calculated from Eq. (6) that when $t_{T}=90 \mathrm{~d}, f_{\mathrm{s}, \mathrm{r}} / f_{\mathrm{cu}, \mathrm{s}}^{28 \mathrm{~d}}<1.0$. It can be concluded that under the field curing condition of this test, when $t_{T}$ was more than $90 \mathrm{~d}$, the rebound method calculated strength cannot reach $f_{\mathrm{cu}, \mathrm{s}}^{28 \mathrm{~d}}$. Therefore, the compressive strength of structural concrete cannot be evaluated only by the rebound method calculated strength.

\section{Conclusions}

This paper investigated the compressive strength of structural concrete by four concrete strength indexes. Based on the experimental results, the following conclusions can be drawn:

1. When $t_{T}$ was $28 \mathrm{~d}$, the compressive strength of fieldcured cubes and core specimens cannot reach that of standard-cured cube specimens because of the differences in casting processes and curing conditions. They tended to be equal to the compressive strength of standard-cured specimens when $t_{T}$ was more than $60 \mathrm{~d}$.

2. The compressive strength of standard-cured specimens and field-cured cubes, and the rebound method calculated strength all had good correlations with that of core samples. The compressive strength of cores with $\Phi 50 \mathrm{~mm}$ and $\Phi 75 \mathrm{~mm}$ was in close proximity to that of $\Phi 100 \mathrm{~mm}$, indicating that the size effect on the compressive strength of core samples was not obvious.

3. All four concrete strength indexes $f_{\mathrm{cu}, \mathrm{s}}, f_{\mathrm{cu}, \mathrm{f}}, f_{\mathrm{s}, \mathrm{c}}$ and $f_{\mathrm{s}, \mathrm{r}}$ developed in a logarithmic growth trend with the increasing equivalent age. It was unrealistic to require $f_{\text {cu,f }}$ to reach $f_{\text {cu,s }}$ when $t_{T}$ was $28 \mathrm{~d}$ based on the development trend of $f_{\mathrm{cu}, \mathrm{f}}$. To evaluate the compressive strength of structural concrete only by $f_{\mathrm{s}, \mathrm{r}}$ was conservative because even when $t_{T}$ was more than $90 \mathrm{~d}$, the rebound method calculated strength still cannot reach $f_{\mathrm{cu}, \mathrm{s}}^{28 \mathrm{~d}}$.

\section{Acknowledgement}

The present work has been conducted with the financial support from the Chinese National Natural Science Foundation (Grant No. 51978205) and the State Scholarship Fund of the China Scholarship Council, with which the first author spent one-year sabbatical in structural engineering research at the University of Houston. 


\section{References}

[1] Unanwa, C., Mahan, M. "Statistical Analysis of Concrete Compressive Strengths for California Highway Bridges", Journal of Performance of Constructed Facilities, 28(1), pp. 157-167, 2014. https://doi.org/10.1061/(ASCE)CF.1943-5509.0000404

[2] Kaltakci, M. Y., Arslan, M. H., Korkmaz, H. H., Ozturk, M. "An investigation on failed or damaged reinforced concrete structures under their own-weight in Turkey", Engineering Fail Analysis, 14(6), pp. 962-969, 2007.

https://doi.org/10.1016/j.engfailanal.2006.12.005

[3] Caspeele, R., Taerwe, L. "Bayesian assessment of the characteristic concrete compressive strength using combined vague-informative priors", Construction and Building Materials, 28(1), pp. 342-350, 2012.

https://doi.org/10.1016/j.conbuildmat.2011.08.065

[4] Naderi, M. "Using Twist-Off Method for Measuring Surface Strength of Concretes Cured under Different Environments", Journal of Materials in Civil Engineering, 23(4), pp. 385-392, 2011. https://doi.org/10.1061/(ASCE)MT.1943-5533.0000176

[5] Bentur, A., Jaegermann, C. "Effect of Curing and Composition on the Properties of the Outer Skin of Concrete", Journal of Materials in Civil Engineering, 3(4), pp. 252-262, 1991. https://doi.org/10.1061/(ASCE)0899-1561(1991)3:4(252)

[6] Price, W. F., Hynes, J. P. "In-situ strength testing of high strength concrete", Magazine of Concrete Research, 48(176), pp. 189-197, 1996.

https://doi.org/10.1680/macr.1996.48.176.189

[7] Chmielewski, T., Konopka, E. "Statistical evaluations of field concrete strength", Magazine of Concrete Research, 51(1), pp. 45-52, 1999.

https://doi.org/10.1680/macr.1999.51.1.45

[8] Chidiac, S. E., Moutassem, F., Mahmoodzadeh, F. "Compressive strength model for concrete", Magazine of Concrete Research, 65(9), pp. 557-572, 2013.

https://doi.org/10.1680/macr.12.00167

[9] Giannini, R., Sguerri, L., Paolacci, F., Alessandri, S. "Assessment of concrete strength combining direct and NDT measures via Bayesian inference", Engineering Structures, 64, pp. 68-77, 2014. https://doi.org/10.1016/j.engstruct.2014.01.036

[10] Hoła, J., Schabowicz, K. "New technique of nondestructive assessment of concrete strength using artificial intelligence", NDT \& E International, 38(4), pp. 251-259, 2005. https://doi.org/10.1016/j.ndteint.2004.08.002

[11] Pucinotti, R. "Assessment of in situ characteristic concrete strength", Construction and Building Materials, 44, pp. 63-73, 2004. https://doi.org/10.1016/j.conbuildmat.2013.02.041

[12] Chen, X., Wu, S., Zhou, J. "Variability of Compressive Strength of ConcreteCcores", Journal of Performance of Constructed Facilities, 28(4), 2014.

https://doi.org/10.1061/(ASCE)CF.1943-5509.0000513
[13] Chen, X., Wu, S., Zhou, J. "Compressive Strength of Concrete Cores with Different Lengths", Journal of Materials in Civil Engineering, 26(7), 2014. https://doi.org/10.1061/(ASCE)MT.1943-5533.0000925

[14] Ariöz, Ö., Tuncan, M., Ramyar, K., Tuncan, A. "A comparative study on the interpretation of concrete core strength results", Magazine Concrete Research, 58(2), pp. 117-122, 2006. https://doi.org/10.1680/macr.2006.58.2.117

[15] Hanson, J. M. "Survey of Practice to Determine Strength of In Situ Concrete from Core Tests", Journal of Performance of Constructed Facilities, 21(1), pp. 22-25, 2007. https://doi.org/10.1061/(ASCE)0887-3828(2007)21:1(22)

[16] ACI "ACI 318-11 Building Code Requirements for Structural Concrete (ACI 318-11) and Commentary", American Concrete Institute, Farmington Hills, MI, USA, 2011.

[17] Fédération Internationale du Béton (fib) "fib Model Code for Concrete Structures 2010", Wilhelm Ernst \& Sohn, Berlin, Germany, 2013.

[18] China Academy of Building Research "GB50204-2015 Code for acceptance of constructional quality of concrete structures", Architecture Industry Press, Beijing, China, 2015.

[19] China Association for Engineering Construction Standardization "CECS 03: 2007 Technical specification for testing concrete strength with drilled core", Architecture Industry Press, Beijing, China, 2007.

[20] Shaanxi Architectural Scientific Research Institute "JGJ/T 23-2011 Technical specification for inspecting of concrete compressive strength by rebound method", Architecture Industry Press, Xi'an, China, 2011.

[21] China Academy of Building Research "GB/T 50081-2002 Standard for test method of mechanical properties on ordinary concrete", Architecture Industry Press, Beijing, China, 2003.

[22] Yazıc1, Ş., Sezer, G. İ. "The effect of cylindrical specimen size on the compressive strength of concrete", Building and Environment, 42(6), pp. 2417-2420, 2007. https://doi.org/10.1016/j.buildenv.2006.06.014

[23] Indelicato, F. "A statistical method for the assessment of concrete strength through microcores", Materials and Structures, 26, pp. 261267, 1993. https://doi.org/10.1007/BF02472947

[24] Vu, X. H., Daudeville, L., Malecot, Y. "Effect of coarse aggregate size and cement paste volume on concrete behavior under high triaxial compression loading", Construction and Building Materials, 25(10), pp. 3941-3949, 2011. https://doi.org/10.1016/j.conbuildmat.2011.04.026 